\title{
Severe pneumonia with formation of a pulmonary cavity associated with long-term rituximab therapy in multiple sclerosis
}

\author{
Carolin Schwake and Ralf Gold ${ }^{*}$ (D
}

\begin{abstract}
Nowadays B-cell depletion via anti-CD20 antibodies is commonly applied in the treatment of multiple sclerosis (MS). Yet, not much is known about infection risks associated with long-term B-cell depletion in the specific context of MS.

We present the case of a 45-year-old male patient who developed severe pneumonia following 6 years of rituximab treatment for highly active relapsing-remitting MS. The patient had no additional chronic disease as well as no history of foreign travel. Although the unusual formation of a pulmonary cavity raised suspicion for tuberculosis, repeated testing via bronchoscopy and sputum remained negative. Prolonged antibiotic therapy with piperacillin/tazobactam and amoxicillin/ clavulanate led to complete recovery from symptoms.

This case shows the potential risk of serious infections following continuous B-cell depletion in MS and illustrates the importance of future vigilance.
\end{abstract}

Keywords: Multiple sclerosis, Rituximab, Pneumonia, Pulmonary cavity

\section{Introduction}

Initially emerging from the therapy of B-cell neoplasms, the mouse/human chimeric anti-CD20 antibody rituximab opened new pathways in treatment of autoimmune disease. Off-label use of rituximab was shown to be effective and well-tolerated in relapsing-remitting multiple sclerosis (RRMS) [1]. Nevertheless, data on the safety of long-term rituximab administration in MS are scarce.

We herein report the case of a 45-year-old male patient who developed severe pneumonia with formation of a pulmonary cavity following 6 years of rituximab treatment for highly active RRMS.

\section{Case report}

The patient presented to our outpatient clinic for the first time in 2014. He had a history of previously diagnosed, untreated RRMS and suffered from brain stem

\footnotetext{
* Correspondence: ralf.gold@rub.de

Department of Neurology, St. Josef-Hospital, Ruhr-University Bochum, Gudrunstr. 56, 44791 Bochum, Germany
}

symptoms with vertical nystagmus and loss of visual acuity. Because of high clinical and gadoliniumenhancing activity B-cell depleting therapy with rituximab was implemented. The patient received regular infusions of rituximab $(500 \mathrm{mg})$ every six to eight months. Treatment intervals were individualized based on CD19+ B-cell monitoring. Over the time span of 6 years the patient suffered from trigeminal neuralgia and an increasing gait ataxia, but overall his clinical condition remained relatively stable (EDSS 3,5). He had no other chronic disease and no history of foreign travel.

In January 2020 the patient developed progressive weakness and night sweats. Because of a productive cough, chest $\mathrm{x}$-ray was performed and revealed an infiltration of the right upper lung. Empiric antibiotic treatment with ampicillin/sulbactam was prescribed for 7 days for community acquired pneumonia. However, 6 weeks later, another $\mathrm{x}$-ray documented the formation of a cavitary lesion (Fig. 1). A computed tomography of the chest revealed engagement of the upper and inferior lobe

(c) The Author(s). 2020 Open Access This article is licensed under a Creative Commons Attribution 4.0 International License, which permits use, sharing, adaptation, distribution and reproduction in any medium or format, as long as you give appropriate credit to the original author(s) and the source, provide a link to the Creative Commons licence, and indicate if changes were made. The images or other third party material in this article are included in the article's Creative Commons licence, unless indicated otherwise in a credit line to the material. If material is not included in the article's Creative Commons licence and your intended use is not permitted by statutory regulation or exceeds the permitted use, you will need to obtain permission directly from the copyright holder. To view a copy of this licence, visit http://creativecommons.org/licenses/by/4.0/. 


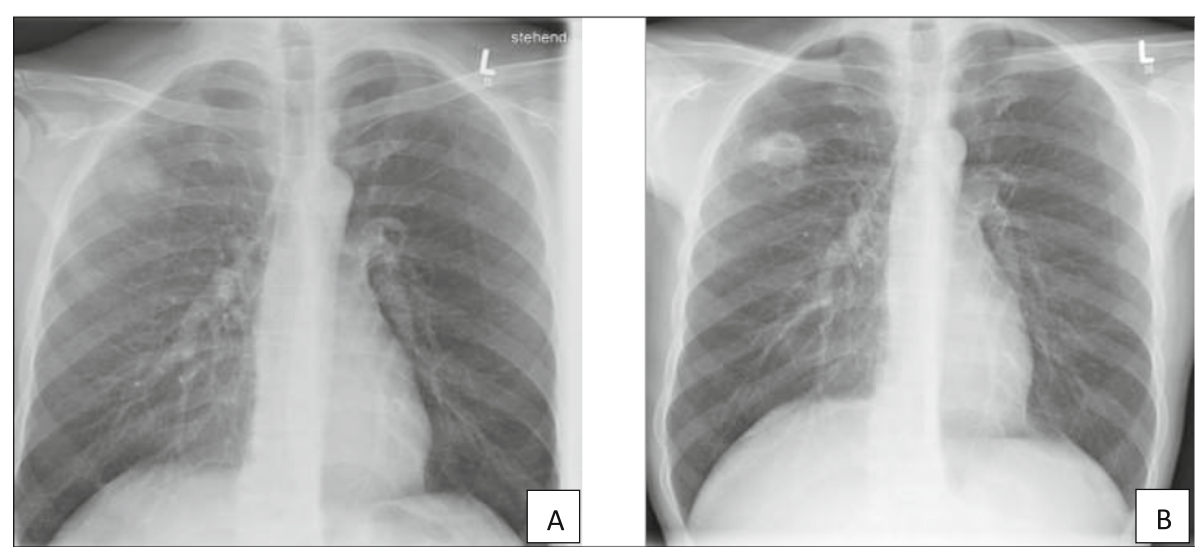

Fig. 1 chest X-rays performed in January (a) and February (b) documenting the formation of a cavitary lung lesion over the time span of 6 weeks

of the right lung (Fig. 2). Blood testing showed an elevation of leukocytes $(12,200$ leukocytes/ $\mu \mathrm{L}, 83 \%$ neutrophils) and CRP $(68 \mathrm{mg} / \mathrm{L})$. Consequently, the patient was admitted to the hospital for extended diagnostic workup. A transbronchial biopsy verified granulocytic inflammation. No evidence of malignancy was found. Repeated testing for tuberculosis, fungi and bacteria remained all negative. Intravenous antibiotic therapy with piperacillin/tazobactam was given for 12 days followed by oral treatment with amoxicillin/ clavulanate for another 7 days. Therapy resulted in gradual clinical improvement and regression of CRP values.

Further immunological evaluation demonstrated complete depletion of CD19+ B-cells. For the first time, the serum IgG level was analyzed and shown to be slightly decreased (IgG $6.30 \mathrm{~g} / \mathrm{L}$, normal range 7.0-16-0 g/L).

\section{Discussion}

Over a decade ago, the 48-week phase II HERMES trial for RRMS showed a similar incidence of infections in patients treated with rituximab $(69,6 \%)$ and placebo (71, $4 \%)$. Since then, the safety profile of B-cell depleting therapy with rituximab in MS is still of great interest.

Two large Swedish studies provide more recent data and estimate an overall higher infectious risk in this context. A retrospective observational multicenter study by Salzer et al. (2016) identified infections as most common non infusion related adverse events [2]. Moreover, Luna et al. (2019) came to the conclusion that rituximab led to the highest rate of serious infections in MS therapy (incidence rate 19,7 per 1000 person-years) as compared to fingolimod $(14,3)$, natalizumab $(11,4)$ and injectables $(8,9)[3]$. Mean duration of rituximab treatment in these studies was 21,6 months [2], respectively 2.0 patientyears [3].

It remains unclear if B-cell depleting therapy for MS increases infectious complications over time. We here report an interesting case of an otherwise healthy individual who developed severe pneumonia after 6 years of long-term rituximab therapy.

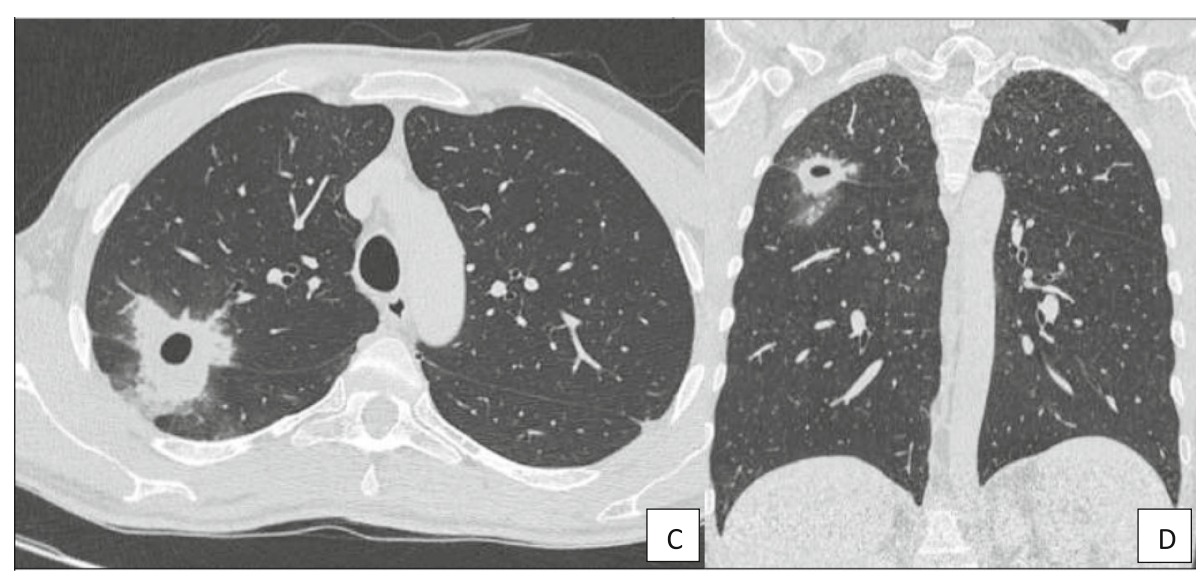

Fig. 2 Involvement of the right upper and inferior lung lobe shown in chest CT in transverse (c) and coronal view (d) 
Analysis of long-term rituximab treatment (36 months to 7 years) in different auto-immune neurological disorders revealed no particular serious adverse events. Yet, only 29 patients were included in this study [4]. On the other hand, rituximab maintenance therapy was shown to increase infection risks as a result of neutropenia and hypogammaglobulinemia in hematological [5], rheumatological or auto-immune disorders [6].

In a cohort of 50 NMOSD patients hypogammaglobulinemia occurred in $64 \%$ after long-term rituximab treatment and led to severe infections in 5 cases. In contrast to our patient, IgG levels were found to be much lower (3.1 to $5.1 \mathrm{~g} / \mathrm{L}$ ) [7].

Another noteworthy aspect is the formation of a complicating pulmonary cavitary lesion. Suspicion of an underlying opportunistic agent was high. According to the literature, infections with Pneumocystis jirovecii associated to rituximab are rare if $\mathrm{CD} 20 \mathrm{~B}$-cell depletion is the only cause for immunosuppression [8]. Tbc reactivation under rituximab may occur [9], but it is still under discussion to what extent. Pulmonary nocardiosis sometimes can mimic tuberculosis in immunosuppressed patients [10]. Yet, diagnostic work-up (including invasive sampling) did not provide any pathogen identification in our patient and only prolonged antibiotic treatment eventually led to gradual improvement.

For conclusion, further attention to evaluate long-term safety of B-cell depletion in MS treatment is needed.

\section{Abbreviations}

CRP: C-reactive protein; EDSS: Expanded disability Status Scale; HERMES: Helping to Evaluate Rituxan in Relapsing-Remitting Multiple Sclerosis; HIV: Human acquired immunodeficiency virus; NMOSD: Neuromyelitis optica spectrum disorders; RRMS: Relapsing-remitting Multiple Sclerosis

\section{Authors' contributions}

CS: acquisition of data, analysis and interpretation of data, drafting of the manuscript. RG: acquisition of data, analysis and interpretation of data, revising the manuscript, study supervision. The authors read and approved the manuscript.

\section{Funding}

There was no funding of this case-report.

\section{Availability of data and materials}

Not applicable.

\section{Consent for publication}

Consent has been obtained.

\section{Competing interests}

CS has nothing to report.

$\mathrm{RG}$ received speaker's and board honoraria from Baxter, Bayer Schering, Biogen Idec, CLB Behring, Genzyme, Merck Serono, Novartis, Stendhal, Talecris, and Teva. His department received grant support from Bayer Schering, Biogen Idec, Genzyme, Merck Serono, Novartis, and Teva. All not related to the content of this manuscript.
Received: 12 May 2020 Accepted: 19 June 2020

Published online: 12 October 2020

\section{References}

1. Hauser, S. L., Waubant, E., Arnold, D. L., et al. (2008). B-cell depletion with rituximab in relapsing-remitting multiple sclerosis. The New England Journal of Medicine, 358(7), 676-688.

2. Salzer, J., Svenningsson, R., Alping, P., et al. (2016). Rituximab in multiple sclerosis: A retrospective observational study on safety and efficacy. Neurology., 87(20), 2074-2081.

3. Luna, G., Alping, P., Burman, J., et al. (2019). JAMA Neurology, 77(2). https:// doi.org/10.1001/jamaneurol.2019.3365. Online ahead of print.

4. Memon, A. B., Javed, A., Caon, C., et al. (2018). Long-term safety of rituximab induced peripheral B-cell depletion in autoimmune neurological diseases. PLoS One, 13(1), e0190425.

5. Aksoy, S., Dizdar, O., Hayran, M., \& Harputluoğlu, H. (2009). Infectious complications of rituximab in patients with lymphoma during maintenance therapy: A systematic review and meta-analysis. Leukemia \& Lymphoma, 50(3), 357-365.

6. Besada, E., Koldingsnes, W., \& Nossent, J. C. (2013). Long-term efficacy and safety of pre-emptive maintenance therapy with rituximab in granulomatosis with polyangiitis: Results from a single Centre. Rheumatology (Oxford, England), 52(11), 2041-2047.

7. Tallantyre, E. C., Whittam, D. H., Jolles, S., et al. (2018). Secondary antibody deficiency: A complication of anti-CD20 therapy for neuroinflammation. Journal of Neurology, 265(5), 1115-1122

8. Martin-Garrido, I., Carmona, E. M., Specks, U., \& Limper, A. H. (2013). Pneumocystis pneumonia in patients treated with rituximab. Chest., 144(1), 258-265.

9. Ottaviani, S., Tiendrebeogo, J., Choudat, L., et al. (2013). Knee tuberculosis under rituximab therapy for rheumatoid arthritis. Joint, Bone, Spine, 80(4), 435-436.

10. Subhash, H. S., Christopher, D. J., Roy, A., \& Cherian, A. M. (2001). Pulmonary nocardiosis in human immunodeficiency virus infection: A tuberculosis mimic. Journal of Postgraduate Medicine, 47(1), 30-32.

\section{Publisher's Note}

Springer Nature remains neutral with regard to jurisdictional claims in published maps and institutional affiliations.
Ready to submit your research? Choose BMC and benefit from:
- fast, convenient online submission
- thorough peer review by experienced researchers in your field
- rapid publication on acceptance
- support for research data, including large and complex data types
- gold Open Access which fosters wider collaboration and increased citations
- maximum visibility for your research: over $100 \mathrm{M}$ website views per year
At BMC, research is always in progress.
Learn more biomedcentral.com/submissions 